\title{
THE INFLUENCE OF SOLUTION HEAT TREATMENT TEMPERATURE ON THE HARDNESS RESPONSE IN INCOLOY ${ }^{\circledR} 945$
}

\author{
MARTINS, I. C. P. ${ }^{1}$, MONTEIRO, W. A. ${ }^{1}$, \\ ANDRADE, A. H. $\mathrm{P}^{1}$ \\ ${ }^{1}$ IPEN (Nuclear and Energy Research Institute); \\ 2242 Lineu Prestes Av.; São Paulo, SP, 05508-000, BRAZIL
}

Keywords: Incoloy ${ }^{\circledR}$ 945, Superalloys, Nickel alloys, Alloys Ni-Fe-Cr, Heat treatments, Solution heat temperature.

\begin{abstract}
The aim of this work is to present the influence of solution heat treatment temperatures study and the corresponding variation on mechanical properties of Incoloy ${ }^{\circledR} 945$ (Ni-Fe-Cr based alloy). The current literature on Incoloy ${ }^{\mathbb{R}} 945$, designed by Special Metals Corporation, disclose that the solution heat treatment temperature is set to the range of $1010^{\circ} \mathrm{C}$ to $1066{ }^{\circ} \mathrm{C}$, where excessive grain growth might occur, which consequently, degrades its mechanical properties. The XRD pattern of the samples heat treated at different solution heat treatments in the present study indicate the presence of the $\gamma^{\prime}$ phase, comprising $\mathrm{Ni}_{3}(\mathrm{Al}, \mathrm{Ti})$. A large decrease in hardness with a small amount of grain growth (ASTM grain size 7) occurs at a temperature of $1020{ }^{\circ} \mathrm{C}$ primarily due to dissolution of the $\gamma^{\prime}$ hardening phase as well as deleterious phases such as the carbides which are not present in a great amount.
\end{abstract}

\section{Introduction}

Nickel based superalloys were developed in the mid-1900s to meet the demand in electricity and to aid the design of gas turbines that were needed to produce it. New materials specifications covering working conditions for this sort of equipment were required, to increase the durability and mechanical properties to achieve increased efficiency of the gas turbine [1]. Still today, superalloys are commonly used in various fields such as the oil, nuclear and aerospace industries. The Incoloy ${ }^{\circledR} 945$ was developed in the first decade of this century as a hybrid alloy with a mechanical strength and corrosion resistance comparable to those of Inconel ${ }^{\circledR} 718$ and Incoloy $^{\circledR}$ 925 , respectively, providing $860 \mathrm{MPa}$ in minimum yield strength and a great combination of ductility as well as impact resistance [2]. Its design was specially developed for applications in the oil and natural gas field $(\mathrm{O} \& \mathrm{G})$. This was due to its high content of $\mathrm{Cr}(19.5$ to $23.0 \mathrm{wt} \%)$, Mo $(3.0$ to $4.0 \mathrm{wt} \%)$ and $\mathrm{Cu}(1.5$ to $3.0 \mathrm{wt} \%)$. The alloy is able to sustain the corrosive environments which are often faced in the $\mathrm{O} \& \mathrm{G}$, which generally contains high levels of chlorides, $\mathrm{S}, \mathrm{H}_{2} \mathrm{~S}$, and $\mathrm{CO}_{2}$ at high temperatures and low $\mathrm{pH}$ conditions. The contents of $\mathrm{Nb}, \mathrm{Al}$, and $\mathrm{Ti}$ leads to precipitation of the intermetallic $\gamma^{\prime \prime}\left[\mathrm{Ni}_{3}(\mathrm{Nb}, \mathrm{Al}, \mathrm{Ti})\right]$ and $\gamma^{\prime}\left[\mathrm{Ni}_{3}(\mathrm{Al}, \mathrm{Ti})\right]$ phases which are responsible for the mechanical strength of the alloy [3].

To increase the amount of these intermetallic phases during the aging, the associated atoms have to be retained in solid solution in the alloy matrix during the preceding solution heat treatment and subsequent quenching to develop a supersaturated solid solution. Deleterious phases as well as carbides are dissolved into the matrix during the solution heat treatment. The higher the solution heat treatment temperature the greater is the grain growth which in turn goes hand in hand with the dissolution of carbides. At a lower temperature, it is possible to dissolve the main 
hardening phases as formed during the aging but still without exhibiting a large grain growth and carbide dissolution [4].

In current literature, the range of $1010{ }^{\circ} \mathrm{C}$ to $1066^{\circ} \mathrm{C}$ is given as the range in which the solution heat treatment is carried out for Incoloy ${ }^{\mathbb{B}} 945$ [5]. However, it does not determine the point where grain growth and subsequently a reduction in mechanical strength take place.

The aim of the present work is to investigate the effect of solution heat treatment in alloy Incoloy ${ }^{\mathbb{B}} 945$ on the mechanical behavior in terms of hardness.

\section{Methodology}

To investigate the solution heat treatment temperature of Incoloy ${ }^{\circledR} 945$, samples were selected for heat treatment, metallographic analysis (optical microscopy) and Vickers hardness testing. Square bar samples of $6.5 \mathrm{~mm}$ in thickness and width, and with a length of $10.5 \mathrm{~mm}$ were manufactured from $127 \mathrm{~mm}$ in diameter rods. The chemical composition of the Incoloy ${ }^{\circledR} 945$ samples are shown in Table I. The as received material was solution heat treated at $1038{ }^{\circ} \mathrm{C}$ for two hours and quenched in water. The samples were subsequently aged at $705^{\circ} \mathrm{C}$ for 8 hours and cooled a rate of $38{ }^{\circ} \mathrm{C}$ per hour to the temperature of $621^{\circ} \mathrm{C}$, where it was kept for an additional 8 hours and 30 minutes followed by air-cooling to room temperature.

Table I. The chemical composition* of the Incoloy ${ }^{\circledR} 945$ material used in the present study.

\begin{tabular}{|ccccccccccccc|}
\hline $\mathrm{Ni}$ & $\mathrm{Cr}$ & $\mathrm{Fe}$ & $\mathrm{Nb}$ & $\mathrm{Mo}$ & $\mathrm{Ti}$ & $\mathrm{Al}$ & $\mathrm{C}$ & $\mathrm{Mn}$ & $\mathrm{Si}$ & $\mathrm{S}$ & $\mathrm{Cu}$ & $\mathrm{P}$ \\
46.96 & 20.48 & 22.42 & 3.07 & 3.19 & 1.55 & 0.17 & 0.01 & 0.06 & 0.07 & 0.001 & 2.01 & 0.008 \\
\hline
\end{tabular}

* Chemical analyses were performed on carbon and sulphur by combustion techniques whereas the other elements were analyzed by Inductively Coupled Plasma Optical Emission Spectrometry (ICP-OES).

The solution heat treatment of the samples were performed at temperatures between 1000 to $1070{ }^{\circ} \mathrm{C}$, at intervals of $10{ }^{\circ} \mathrm{C}$, for 2 hours dwell time followed by quenching in water. The furnace used for the solution treatments do not operate using a controlled atmosphere and can be used at a maximum temperature of $1200{ }^{\circ} \mathrm{C}$. A 304 stainless steel block was used (see Figure I) to induce some "thermal mass" (the larger the mass of heated material the larger the "inertia" against temperature fluctuations).

The furnace was heated to the desired temperature using a heating rate of $30^{\circ} \mathrm{C} / \mathrm{min}$. The furnace door was opened rapidly (10 seconds on an average) in order to place the samples (three pieces) of Incoloy ${ }^{B} 945$ inside the alumina crucible as was located in the furnace (dimensions given in Figure I). This alumina crucible was used to protect the samples from being in contact with the 304 steel. Three samples were used at each test to check the reproducibility of the system. The starting time for the 2 hours heat treatment began 5 minutes after closing the furnace door.

In the upper part of the 304 matrix, there is a cavity for insertion of a $6 \mathrm{~mm} \mathrm{~K}$-type thermocouple, which is located in a position slightly above the position of the specimens (see Figure II). This is the reference thermocouple for temperature control that connects to the thermostat used for temperature measurement. This thermostat is adjusted so that the temperature reading is slow, however, precise and accurate. 
After two hours, the cavity in the matrix is opened, the thermocouple is raised to a height where the alumina crucible can be removed and the specimens are then quenched in water at room temperature $\left(25^{\circ} \mathrm{C}\right)$. The entire procedure takes up to $\sim 10$ seconds.

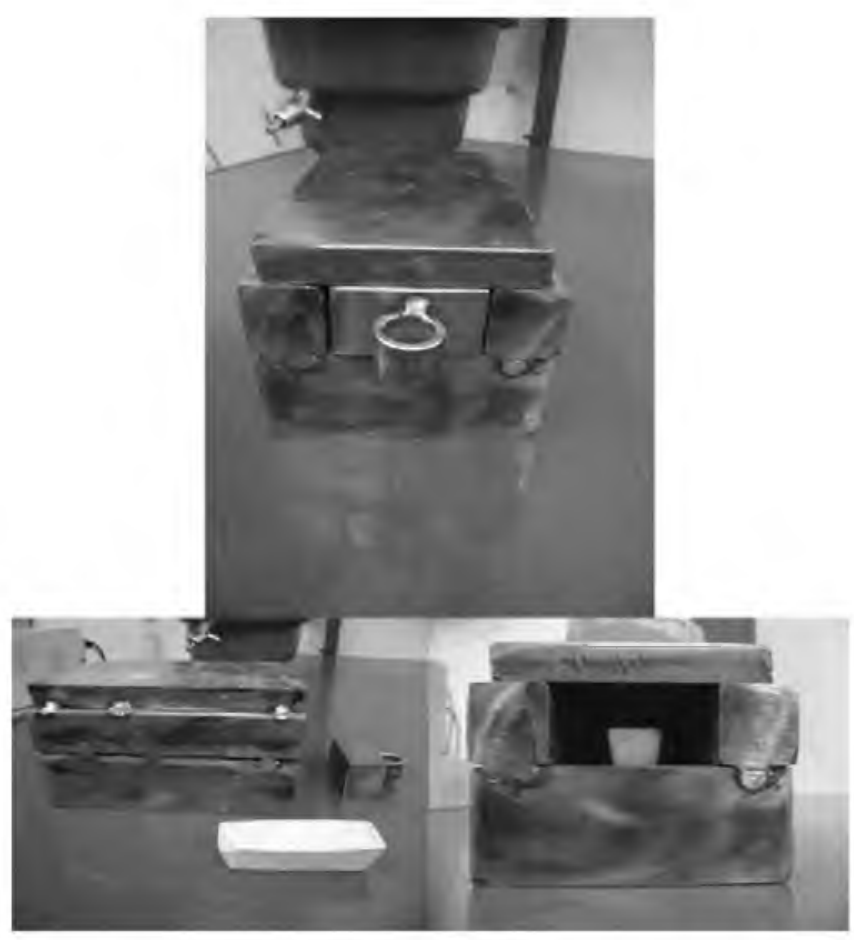

Figure I. The 304 steel matrix with dimensions of $150 \times 100 \times 80 \mathrm{~mm}$. The cavity measured $50 \times 30 \times 100 \mathrm{~mm}$. The dimensions of the alumina crucible are $80 \times 20 \times 20 \mathrm{~mm}$.

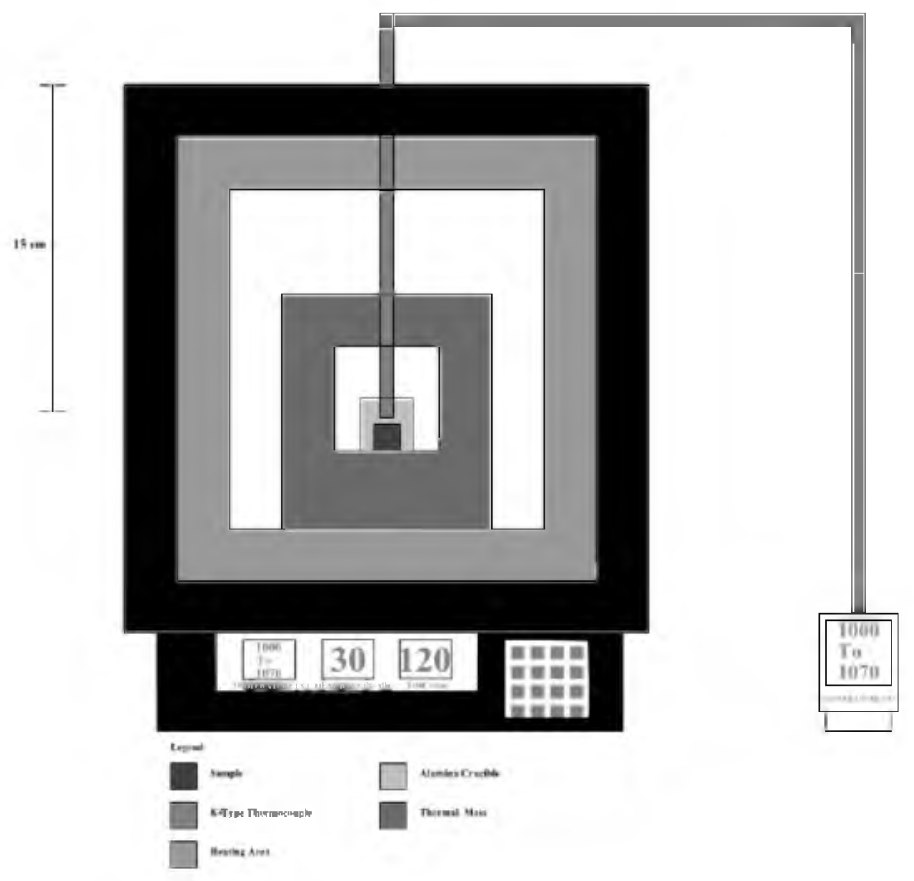

Figure II. The furnace assembly with the 304 steel matrix and K type thermocouple for temperature reference. 
The specimens were mounted in acrylic resin and prepared according to standard procedure as described in Table II.

Table II. Steps used for the metallographic preparation of samples for optical microscopy and Vickers hardness testing.

\begin{tabular}{|c|c|c|c|c|c|c|}
\hline Step & Abrasive Disc (Grit) & Micron Grading $(\mu \mathrm{m})$ & Time (s) & Pressure (lbf) & RPM & Lubricant \\
\hline 1 & 240 & 52 & $* 1$ & & \multirow{6}{*}{80} & \multirow{6}{*}{ Water } \\
\hline 2 & 320 & 35 & & & & \\
\hline 3 & 400 & 22 & & & & \\
\hline 4 & 600 & 15 & 540 & 3 & & \\
\hline 5 & 800 & 10 & & & & \\
\hline 6 & 1200 & 5 & & & & \\
\hline 7 & Colloidal Silica & 0.02 & 720 & & 10 & None \\
\hline
\end{tabular}

*1 -Grinding until flat and parallel.

A chemical etchant as developed by the Special Metals Corporation and known as the "seven reagent" acid was used. The solution consists of $300 \mathrm{ml}$ of distilled water, $300 \mathrm{ml}$ of hydrochloric acid $(\mathrm{HCl}) 37 \%, 60 \mathrm{ml}$ glacial acetic acid $(\mathrm{CH} 3 \mathrm{COOH}) 99.7 \%, 60 \mathrm{ml}$ nitric acid $\left(\mathrm{HNO}_{3}\right) 65 \%, 60 \mathrm{ml}$ phosphoric acid $\left(\mathrm{H}_{3} \mathrm{PO}_{4}\right) 85 \%, 30 \mathrm{ml}$ sulfuric acid $\left(\mathrm{H}_{2} \mathrm{SO}_{4}\right) 98 \%, 30 \mathrm{ml}$ of hydrofluoric acid (HF) $30 \%$ and $30 \mathrm{~g}$ of iron (III) chloride $\left(\mathrm{FeCl}_{3}\right)$ [5] .

The metallographic specimens were immersed for four minutes in the acid solution, rinsed in water and ethanol followed by drying in hot air. However, if the attack is not done properly, in a time less than four minutes, a high chromium content film is formed causing the exposure to the acid attack to become ineffective [6].

The Vickers hardness tests were performed in a Buehler Series 5100 tester, according to ASTM E384-11 [7]. A load of 500 gf (gram-force) for 15 seconds was used. The indents were not placed closer than $2 \mathrm{~mm}$ from the edge of the sample and 10 Vickers hardness measurements were performed along the central line of the sample. From these 10 measures, the highest and lowest values were excluded. The arithmetic mean is calculated and presented along with its standard deviation.

After the hardness test, X-ray diffraction characterization was done in order to determine the phases present in the samples. A Rigaku Desktop diffractometer Miniflex II were used, using the following parameters: $30 \mathrm{kV}, 15 \mathrm{~mA}, 20 \mathrm{o}<2 \theta<100 \mathrm{o}, \Delta 2 \theta=0.05 \mathrm{o}, \Delta \mathrm{t} / \mathrm{Step}(2 \theta)=2 \mathrm{~s}, \lambda \mathrm{CuK} \alpha$. The characterization of the diffraction peaks were done in the Crystallographica Search-Match program.

\section{Results and Discussion}

The austenitic alloy Incoloy ${ }^{\circledR} 945$, do commonly (depending on the processing condition) reveal phases such as $\gamma^{\prime}\left[\mathrm{Ni}_{3}(\mathrm{Al}, \mathrm{Ti})\right], \gamma^{\prime \prime}\left[\mathrm{Ni}_{3}(\mathrm{Nb}, \mathrm{Al}, \mathrm{Ti})\right], \mathrm{NbC}$ carbides and deleterious phases such as eta, $\eta[\mathrm{Ni} 3 \mathrm{Ti}]$, and sigma, $\sigma[\mathrm{Ni}+\mathrm{Cr}+\mathrm{Fe}]$.

The major hardening phases in Incoloy ${ }^{\mathbb{B}} 945$ are the $\gamma^{\prime}$ and $\gamma^{\prime \prime}$ phases. To achieve a most efficient aging process for these hardening phases one should have the largest possible number of atoms $(\mathrm{Ni}, \mathrm{Al}, \mathrm{Ti}$ and $\mathrm{Nb}$ ) dissolved within the austenitic matrix during the preceding solution heat treatment. 
For this process to occur, a solution heat treatment of the material should be performed in which all the precipitates (both beneficial and deleterious) are dissolved in the solid solution matrix from which they can be precipitated in the following aging.

Figure III shows the Vickers hardness after solution heat treatment. The as received hardness of the material was $(474 \pm 10) \mathrm{HV}$. Among the investigated temperatures, the heat treatment at $1000{ }^{\circ} \mathrm{C}$ caused a reduction in hardness of around $61 \%$, reaching $66 \%$ at the temperature of 1070 ${ }^{\circ} \mathrm{C}$. In comparison between $1010{ }^{\circ} \mathrm{C}$ and $1020^{\circ} \mathrm{C}$, there was a great reduction in hardness. At the examined temperatures, the treatment at $1000^{\circ} \mathrm{C}$ caused a reduction of hardness of around $61 \%$, reaching $66 \%$ at the temperature of $1070{ }^{\circ} \mathrm{C}$. Between $1010{ }^{\circ} \mathrm{C}$ and $1020{ }^{\circ} \mathrm{C}$, the reduction in hardness was highest.

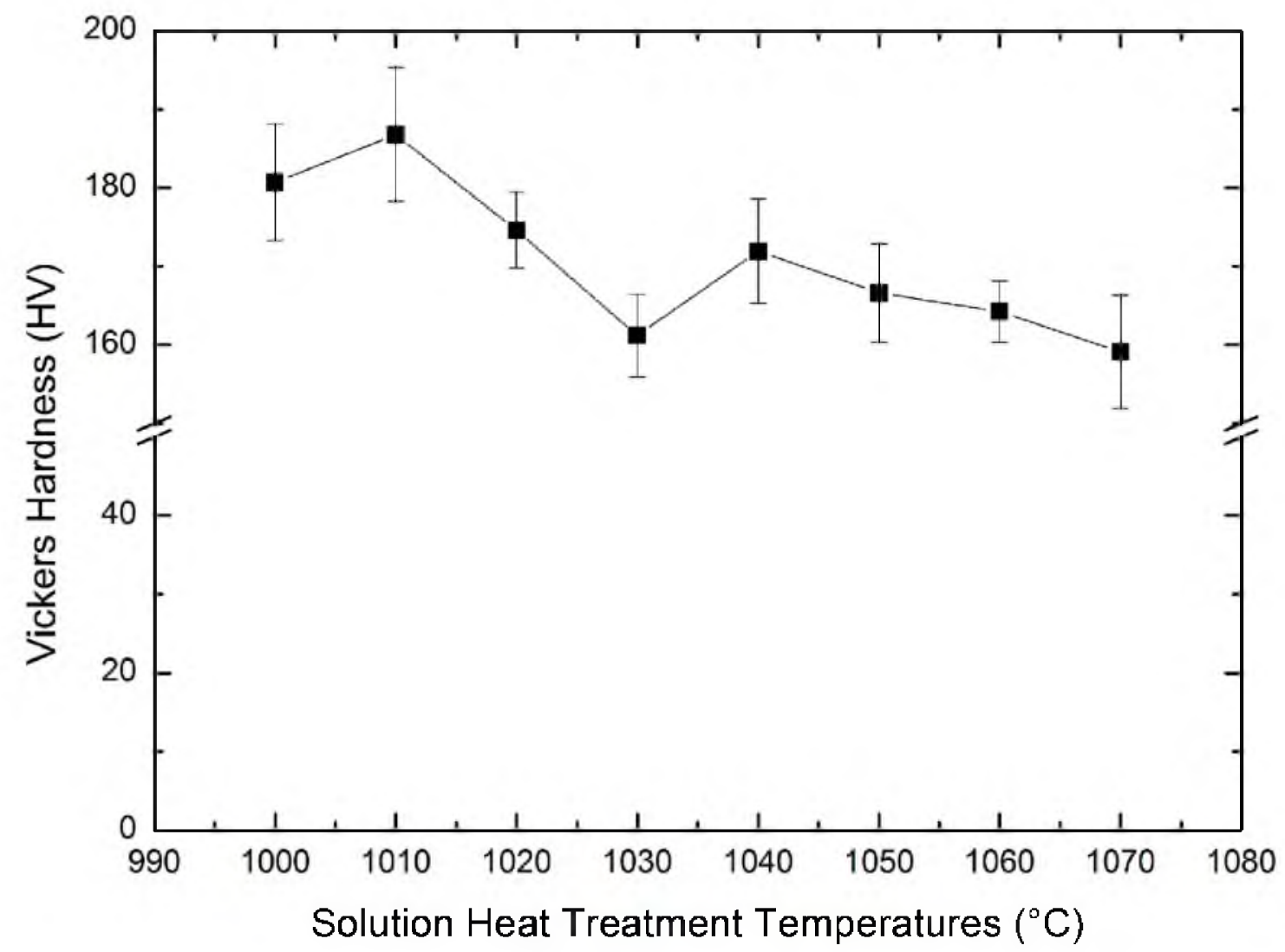

Figure III. Vickers hardness versus different solution heat treatments temperatures.

The micrographs are shown in figures IV, V and VI. ASTM E112-12 [8] was used to quantify the grain size to be able to correlate it with the reduction of hardness in the material. 

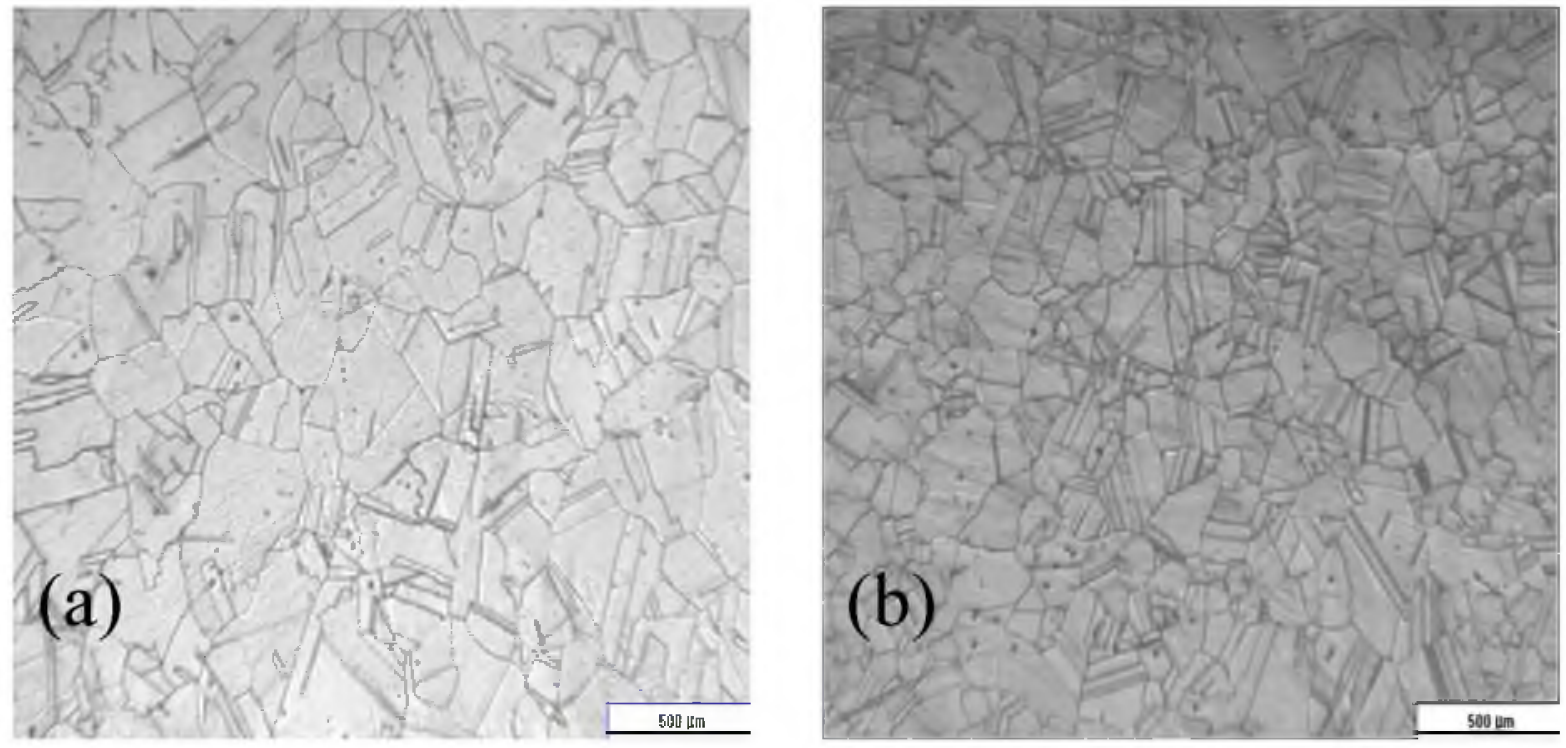

Figure IV. Optical microscopy: a) As received material; b) Material solution heat-treated at $1000{ }^{\circ} \mathrm{C}-2 \mathrm{~h}$.
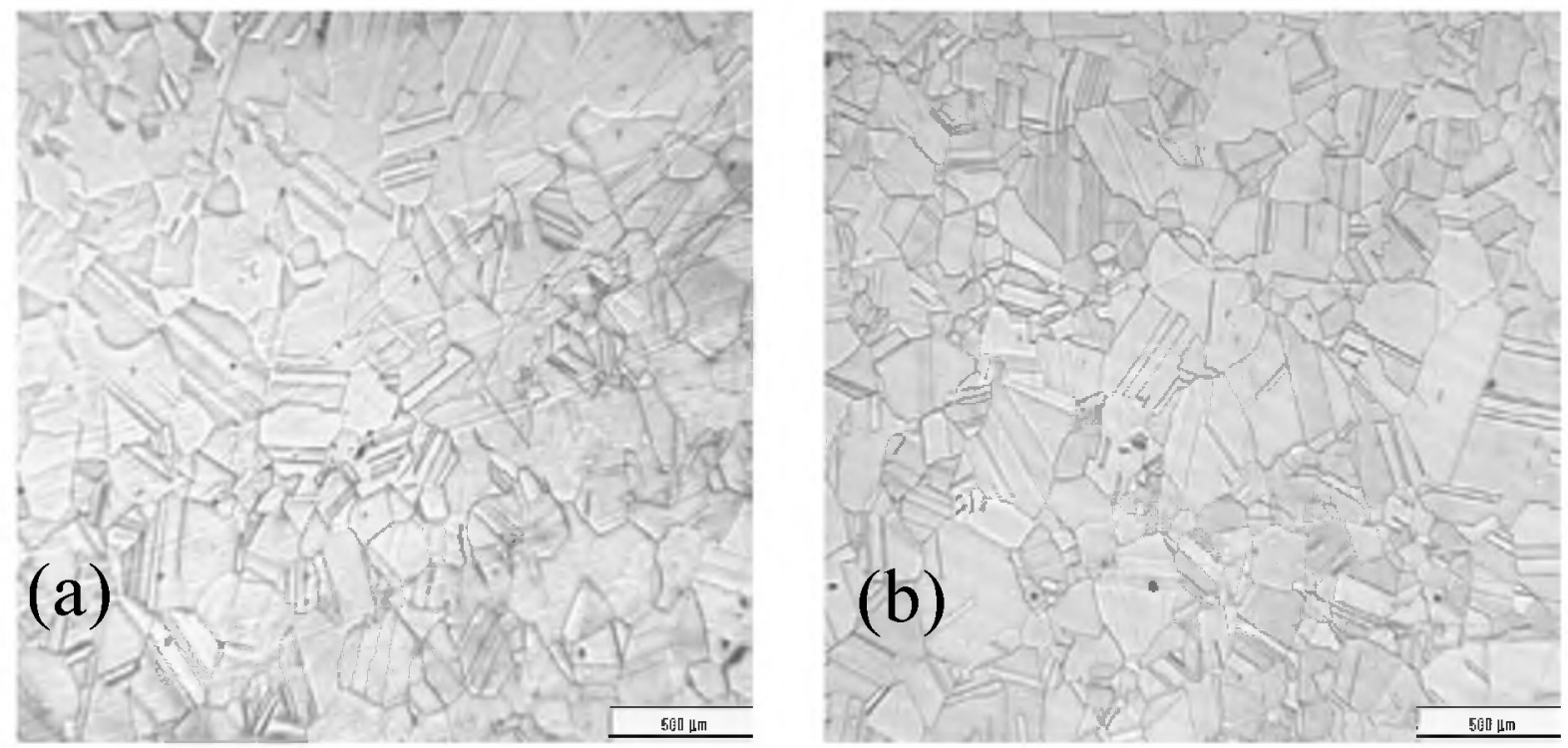

Figure V. Optical microscopy: a) Material solution heat -treated at $1020{ }^{\circ} \mathrm{C}-2 \mathrm{~h}$; b) Material solution heat-treated at $1040{ }^{\circ} \mathrm{C}-2 \mathrm{~h}$. 

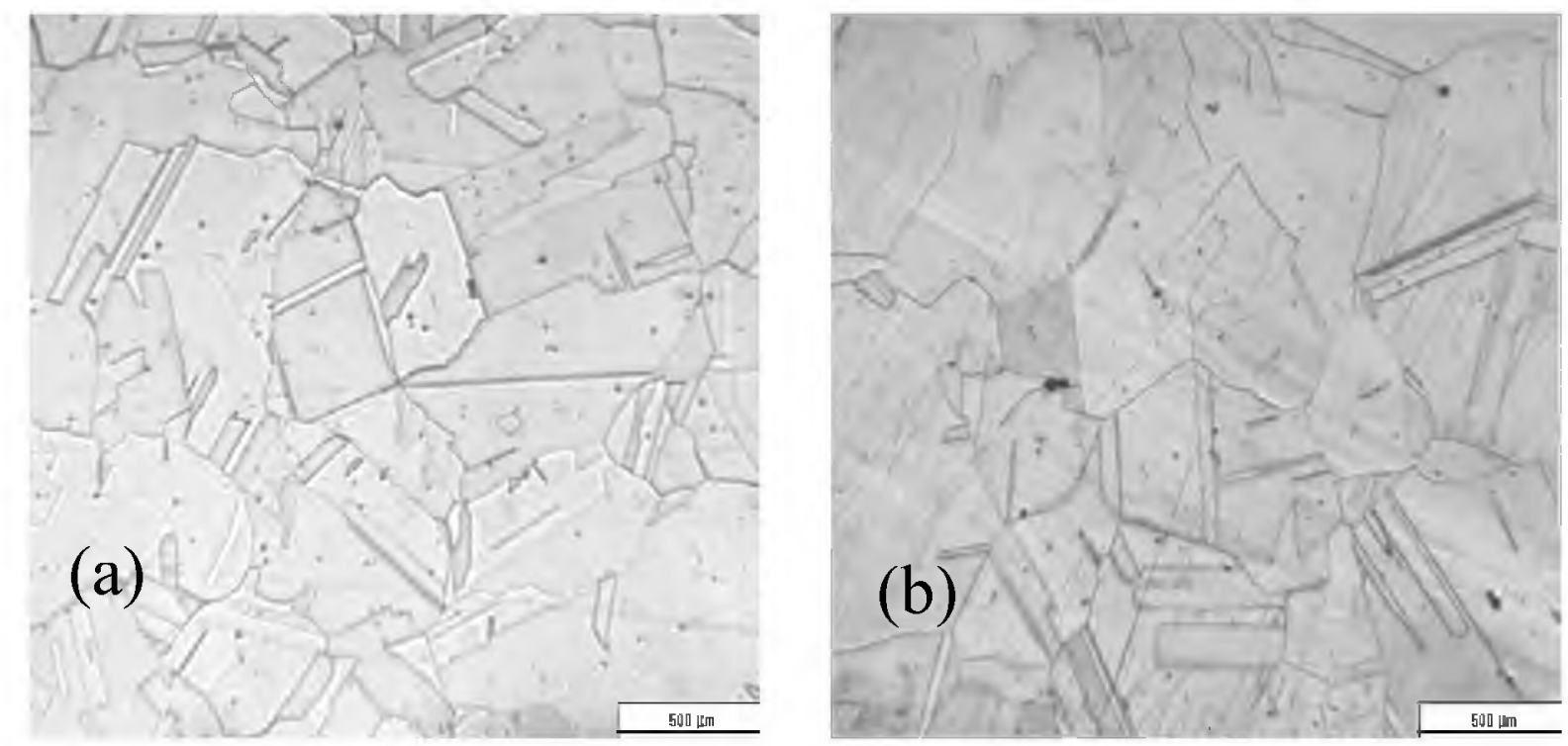

Figure VI. Optical microscopy: a) Material solution heat treated at $1060{ }^{\circ} \mathrm{C}-2 \mathrm{~h}$; b) Material solution heat-treated at $1070{ }^{\circ} \mathrm{C}-2 \mathrm{~h}$.

Considering the grain size, the as received sample had a grain size of ASTM 7, while the materials heat-treated at $1020,1040,1060$ and $1070{ }^{\circ} \mathrm{C}$ had an grain size of ASTM 7, 6, 2, and 2, respectively. This indicates that as the solution heat treatment temperature increases, the grain size increases Considering the hardness, the larger the grain size the lower the hardness due to the Hall-Petch effect [9].

Figure VIII disclose the $\mathrm{x}$-ray diffraction pattern of the alloy samples after heat treatment at temperatures ranging from 1000 to $1070{ }^{\circ} \mathrm{C}$ for a two hours dwell time.

The XRD pattern of the as received condition, as well as all the other conditions do only indicate the presence of the $\gamma^{\prime}$ phase, comprising [ $\left.\mathrm{Ni}_{3}(\mathrm{Al}, \mathrm{Ti})\right]$, as reported by $\mathrm{S}$. Mannan [3]. This author also reports the presence of $\gamma^{\prime \prime}$, carbides, $\eta$, and $\sigma$ phases. However, the temperature range in which the experiments were conducted in the present investigation do according to an isothermal transformation diagram (TTT diagram) [3] only suggest the formation of the $\gamma^{\prime}$ phase.

In the samples that were heat treated above $1050^{\circ} \mathrm{C}$, the peaks at $90.5^{\circ}$ (figure VIII) have an intensity higher than the others, which is due to the fact that the sample contain a crystallographic texture, that is, the grains are preferentially oriented in one direction. For temperatures above $1050{ }^{\circ} \mathrm{C}$, the grains grow to an average diameter of $180 \mu \mathrm{m}$ (ASTM 2). So the focus of the X-ray beam diffracts only a few grains of the sample reducing the effect of the crystallographic texture in the spectrum. 


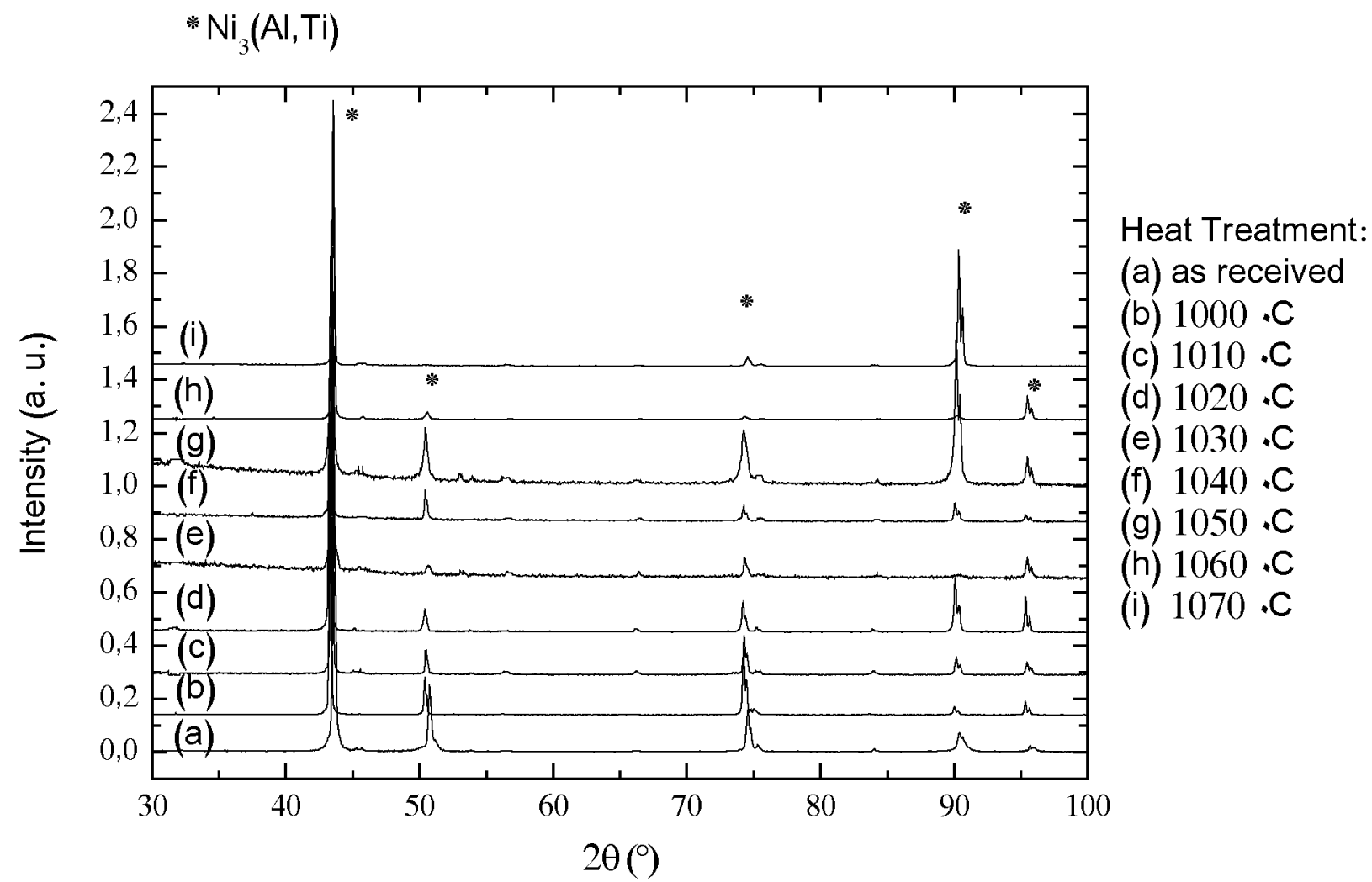

Figure VIII. Standard X-ray diffraction of the samples, as received and solution heat-treated conditions.

\section{Conclusion}

According to the collected data in this investigation of the effect of solution heat treatment response in the range of 1000 to $1070{ }^{\circ} \mathrm{C}$ ( 2 hours dwell time) on the hardness loss in Incoloy ${ }^{\mathbb{B}}$ 945 , there is a $61-66 \%$ hardness decrease primarily due to dissolution of the $\gamma^{\prime}$ hardening phase. Samples heat treated at $1020{ }^{\circ} \mathrm{C}-2 \mathrm{~h}$ has a hardness decrease of $63 \%$, primarily associated with dissolution of the $\gamma^{\prime}$ phase, with a slight grain growth (ASTM 7). Above this temperature, the hardness loss is negligible, however, the grain growth is more pronounced reaching a grain size of ASTM 2, in the samples treated at $1050{ }^{\circ} \mathrm{C}$ and above. This concludes that the drop in hardness is primarily associated with the dissolution of the $\gamma^{\prime}$ phase and not to the significant grain growth which occurs at around $1050^{\circ} \mathrm{C}$. 


\section{References}

[1] C. T. Sims, "A History of Metallurgy Superalloy ingots for Metallurgists Superalloy ingots," in Superalloys 1984 (5th International Symposium), 1984, pp. 399-419.

[2] S. Mannan and L. Patel, "The New Ni-base Superalloy ingots For Oil and Gas Application," in Superalloys 2008, 2008, pp. 31-39.

[3] S. Mannan, "Time-Temperature-Transformation Diagram of Alloy 945," in: 7th International Symposium on Superalloys 718 and Derivatives, 2010, pp. 629-643.

[4] ASM International, Heat Treating, "in ASM Handbook, 10th, American Society for Metals, 2002.

[5] Special Metals Co., "INCOLOY $®$ alloys 945/945X, 2008.

[6] S. Coryell, Flow Behavior and Microstructural Evolution of INCOLOY $® 945$ During High Temperature Deformation, "Colorado School of Mines, 2010.

[7] ASTM International, "E384-11 Standard Test Method for Knoop and Vickers Hardness of Materials."ASTM International, West Conshohocken, pp. 1-43, 2012.

[8] ASTM Internarional, "E112-12 Standard Test Methods for Determining Average Grain Size.” pp. 1-27, 2013

[9] R. E. Smallman and A. H. W. Ngan, Physical Metallurgy and Advanced Materials, 7 th. 2007, pp. 1-650. 